\title{
Detecting Creative Accounting in Businesses in Financial Distress
}

\author{
Nikolaos Arnis ${ }^{1}$, Konstantinos Karamanis ${ }^{1} \&$ Georgios Kolias ${ }^{1}$ \\ ${ }^{1}$ University of Ioannina, Department of Accounting \& Finance, Preveza, 48100, Greece \\ Correspondence: Nikolaos Arnis, University of Ioannina, Department of Accounting \& Finance, Preveza, 48100, \\ Greece. E-mail: narnis@teiep.gr
}

Received: May 2, 2019

Accepted: May 21, 2019

Online Published: May 22, 2019

doi:10.5430/afr.v8n2p232

URL: https://doi.org/10.5430/afr.v8n2p232

\begin{abstract}
This paper investigates whether the management of firms in financial distress applies creative accounting techniques in order to fine-tune the elements of their financial statements. For this purpose, the financial statements of 385 Greek bankrupt firms of the trade and manufacturing sectors for the period 2003 to 2014 were analyzed. The sample was divided into two sub periods; in the period before the financial crisis, that is from 2003 to 2008 , and the period 2009 to 2014 during which the Greek economy was in crisis and recession. By applying factor analysis, five financial ratios were selected, which formed the independent variables in a Discriminant Analysis (MDA) and Logit models in order to find those firms which, while they were bankrupt they were classified in the last period of their operation as healthy (type I error).By selecting these firms (common to both models), their accounting data for the last two years before they went bankrupt have been investigated in order to determine whether they have been affected by the application of creative accounting methods. The results showed that the management of some of the selected firms applied creative accounting techniques during the last year of operation before their bankruptcy, which led to the manipulation and falsification of the published financial statements during the period before the financial crisis. However, this is not the case for the period 2009 to 2014, because the economic crisis affects the behavior of managers in applying creative accounting, which is owing to the changes in market rules.
\end{abstract}

\section{JEL Classification: C38, C53, G33, M41}

Keywords: creative accounting, financial distress, bankruptcy classification, financial and accounting ratios

\section{Introduction}

The phenomenon of creative accounting over the last 30 years shows an upward trend and, regardless of the reasons firms are driven to it, the disclosure of its application affects the reliability of the financial statements, resulting in an impact on the borrowing cost, the share price, the confidence of investors and regulators, as well as on the company's relationships with its customers and suppliers.

The cases of firms which collapsed under the weight of scandals and creative accounting, concealing their true financial condition, intrigued several researchers on the basis of study of creative accounting applied by the firms' management (see, e.g. (Healy PM, Palepu KG., 2003)).

The directors of firms in financial distress and high risk of bankruptcy, in order to prolong the economic life of their firms, hoping for a better future economic environment, misrepresent the financial statements through appropriate accounting methods and techniques, making their informative content misleading.

(Argenti J., 1976) states that when the enterprise is close to bankruptcy, there is an increased interference by the directors in order to alter the financial statements. (Rezaee Z, Rilay R., 2009) in their book, Financial Statement Fraud Prevention and Detection, report that the characteristics of accounting fraud are the fraudulent alteration of magnitudes, documents or business transactions, omissions or distortions of facts, accounts and other information from the financial statements, the deliberate misapplication, interpretation and implementation of accounting standards, and the use of accounting techniques to manage illicit benefits.

The main reasons why managers and senior executives of firms in financial distress are led to the implementation of methods and techniques of creative accounting, in order to alter the financial data and embellish their financial statements are:

The attempt to restore confidence on the part of the banks, which was disturbed due to delays in repayment of loan obligations and the hope of new financing, so that they could, at least temporarily, overcome the liquidity 
problem.

- In order not to disturb the confidence or in an attempt to restore disturbed relationships with customers and suppliers due to the poor financial position of the business.

- Extending the life of the business so that executives or senior executives, using illegal practices and accounting fraud, can reap benefits before the final collapse and bankruptcy.

- Benefits sought after by managers for as long as the business is alive, given that their compensation is often linked either to the increase in published earnings or to the increase in the share price.

- The resistance to stock collapse and the maintenance of the stock market price of the company.

- The creation of favorable conditions for the takeover of the business by other firms or the defense against takeover attacks by other firms.

- To conceal errors have been made in management.

In order to bring about the deterioration of the financial data and the embellishment of their financial statements, the directors of the firms follow various manipulation practices, which often exceed the limits of legality, and whose application and scope also depend on the mechanisms and procedures (business environment) that apply in each country.

According to (Leuz C, Nanda D, Wysocki P., 2003) and (Bhattacharya U, Daouk H, Welker M., 2003) in countries where the application of legislation is highly lax and investor protection is not appropriate, earnings management is more intensively used.

Creative accounting is usually done by manipulating the accounts of fixed assets, liabilities, sales - revenues, and expenses, but also by changing methods and accounting policies.

Such manipulation practices may include:

- Creating delusive and virtual revenue.

- Manipulating real activities, giving excessive sales discounts at the end of the year.

- Alteration (increase) of the end-of-year inventory resulting in lower cost of goods sold and increase in gross profit.

- Appropriate management of accrued accounts and breach of the accrual principle.

- The avoidance of deletion of spoiled inventories or damaged and non-operating fixed assets.

- Accounting estimates and policies that set the accounting numbers and constitute a hidden form of earnings management, e.g. reduced provisions for bad debts.

- The capitalization of expenses, i.e. the recording of various operating expenses (i.e. expenses of acquired and improving fixed assets) as costs, which are subject to amortization.

- Shifting and offsetting expenses in the next management period.

- Changes in accounting policies (depreciation method, depreciation rate, asset valuation method).

- The conditional policy change in the securities held by the company and their transfer from the investment portfolio to the trading portfolio.

. In general, the non-recording of accounting events that affects the company's finances.

In this paper, factor analysis was used to highlight the independent variables that are most important in predicting business bankruptcy. Applying models of Multiple Discriminant Analysis (MDA) and Logit, it was found that the predictive capacity (classification rate) of both models declined in the last year before bankruptcy, categorizing some of the bankrupt firms as healthy (type I error).

Examining the firms resulting in a type I error in the last year before bankruptcy (i.e. firms which, while bankrupt, appear to be healthy in the next accounting period), it is noted that the improvement in the financial data appearing in their financial statements during the pre-crisis period (2003-2008) is probably due to the exercise of earnings management through techniques and methods of creative accounting. However, this is not the case in the period of Greek crisis (2009-2014) due to changes in managerial behavior of the firms' directors because of the changes in market rules (e.g. changes in credit terms on behalf of suppliers, more tighten lending criteria on behalf of banks etc).This work will help to improve the knowledge of stakeholders, lenders, analysts, suppliers and customers, on the 
techniques of exercising creative accounting used by firms in financial distress before the bankruptcy event occurs, as well as on methods for its detection and tracing.

\section{Literature Review}

According to the relevant literature and the results of the various studies, the managers and directors of firms follow earnings management methods, which vary corresponding to the incentives that exist each time, in order to conceal their real financial situation.

(Jones J., 1991) developed a linear regression model to identify the factors that affect the accruals considering that present a linear relationship to sales changes as well as to fixed assets changes. (Sweeney A., 1994) investigating firms in the US that had failed to meet their obligations, found they had increased profits and cash flows without these being accompanied by a cash increase before the default occurred. Also in $23 \%$ of the firms they investigated, the earnings management exercised resulted in the delay of bankruptcy during one management period. (Dechow P, Sloan R, Sweeney A., 1995) evaluate alternative patterns based on accrual accounting in order to detect earnings management in US firms. (Degeorge F, Patel J, Zeckhauser, R., 1999) examined earnings management as far as the level of profitability is concerned and found that the most important thresholds pursued by businesses are to avoid losses and reduce profits. (Kalunki JP, Martikainen T., 1999) investigated Finnish bankrupt firms and found an upward trend in earnings management over the three years before failure. They conclude that earnings management is an important variable in the process of predicting financial failure. (Smith M, Kestel J, Robinson P., 2001) investigated changes in accounting policy in a sample of Australian firms, one year before the firms became insolvent. The results showed that businesses that are classified as failed show a significant trend in earnings growth. (Rosner RL., 2003) states that creative accounting acts as a defensive strategy for firms that apply it. He investigated whether firms in a state of financial distress have applied creative accounting and showed that firms are applying earnings management methods in order not to show their real financial figures and to embellish their published financial statements. His research focused on US firms for the period 1985-1997. (Roychowdhury S., 2006) reports that managers manipulate real activities to increase profitability, which is achieved by using discounts on sales prices to increase sales, and by producing more products (overproduction), thus increasing end-inventories and lowering the cost of goods sold. (Charitou A, Lambertides N, Trigeorgis L., 2007) and (Charitou A, Lambertides N, Trigeorgis L., 2007) report that firms apply earnings management practices one year before becoming insolvent. (Lara JMG, Osma BG, Neophytou E., 2009) examined behaviors consistent with earnings management in listed firms of the United Kingdom and Ireland during four years before they become insolvent, for the period 1998-2004. They found an upward trend in earnings management in the fourth and second years before firms became insolvent. They focused on earnings management using accrued revenue. (Barua A, Lin S, Sbaraglia A., 2010) found that firms' managers shifted various operating costs in order to increase their profitability. (Beasley MS, Carcello JV, Hermanson DR, Nead TL., 2010) in their study, for the period 1998-2007, report that the most frequent frauds, relate to unjustified income recognition and overestimation of assets. They also report that $26 \%$ of the firms that committed fraud changed their auditor between the latest clean financial statements and the latest financially misleading financial statements. $60 \%$ of the firms that committed fraud changed their auditor during the fraud, while $40 \%$ changed their auditor just before the fraud. (Habib A, Bhuiyan MBU, Islam A., 2013) examined the impact of financial failure on earnings management options in New Zealand's environment, which is characterized by lax monitoring of regulators, and whether the practices of earnings management changed during the economic crisis. They found that the financial distress faced by firms is an incentive for earnings manipulation, and managers of troubled firms are more concerned with earnings management practices than their healthy counterparts. They also found evidence of the impact of the economic crisis on the relationship between economic distress and earnings manipulation. (Bryan D, Janes T, Tiras SL., 2014) examined the relationship between fraud and bankruptcy and the ability of enterprises to reorganize and emerge from bankruptcy. They report that fraudulent financial information designed to cover the deterioration of business finances is not enough to reverse their impending financial collapse. Delaying bankruptcy through earnings management leads the company to a point beyond which the recovery of the business is not feasible. (Campa D, Camacho-Minano M., 2014) are investigating the application of earnings management to non-listed firms in Spain three years before bankruptcy. Their results have shown that firms manage earnings in such a way that allows them to show profitability growth over the three years before bankruptcy, using accrued revenue. They also report a different behavior in earnings management among firms in different industries. (Miko NU, Kamardin H., 2014) report that the efficiency and effectiveness of models that are used for identifying earnings management, depends on the nature of earnings management practices in a particular environment. In their study, they compare five different earnings management detection models in a sample of firms listed on the Nigerian stock exchange and conclude that Jones' (1995) modified model is able to better detect the earnings management applied by managers. (Howe J, 
Houston R., 2016) examined the tendency of troubled firms towards earnings management and the impact on investors' response. They found that firms in financial distress manage earnings considerably more than companies that are not experiencing financial distress. (Dutzi A, Rausch B., 2016) reviewed the existing literature and found that accounting behavior in businesses experiencing problems in the period before failure is ambiguous. (Nagar Neerav, Sen Kaustav., 2016) examine Indian firms' earnings management strategy, which is related to the severity and extent of the economic downturn, and say that the managers of the companies in distress are managing profits in order to cover the unfavorable performance and to obtain more liquidity from the banks, or for their personal benefit. They also report that they are likely to engage in inappropriate revenue recognition and manipulation of expenses, liabilities and accounts receivable. (Humeedat MM., 2018) examines the role of earnings management in order to avoid financial distress and improve profitability in 58 industrial companies listed on the Amman Stock Exchange (Jordan) for the period 2011 to 2016. Empirical results have shown that earnings management is not affected by the outcome of the Altman Z-score model and that there is a positive relationship with the debt to equity ratio, as well as a positive relationship between dividend per share, return on equity, and earnings management.( Ranjbara $S$, Gholamreza FA., 2018), investigating companies listed on the Tehran Stock Exchange for the period 2010-2015, and using linear regression models, concluded that firms in financial distress are more involved in earnings management than companies that do not have financial problems.

From the above review of the literature, it is evident that, indeed, in various periods prior to bankruptcy, a variety of techniques of creative accounting are applied by companies that are in a state of financial distress, and in order to determine the time and scope of their implementation, different methods of analyzing their financial data are followed. Moreover, the economic environment and macroeconomic characteristics, like economic crises, seems to be drivers for the behavior of firms regarding the application of the adaptation of creative accounting methods.

In the present work, at first, classification models were used to classify sample enterprises into bankrupt and non-bankrupt. The predictive failure of the two above-mentioned models in the last year before bankruptcy in relation to the previous years (i.e. the projected reduction in predictive capacity) for some of the sample companies leads us to assume the widespread application of creative methods and techniques of creative accounting during the last year of their operation. This hypothesis is verified by looking at the evolution over time of certain financial magnitudes of companies (such as inventories, sales, profits and losses) and the favorable changes in these figures in the last year before bankruptcy, which resulted in incorrect classification of the companies by the MDA, Logit models showing a number of companies that went bankrupt as healthy.

\section{Data Description}

The data of the bankrupt Greek firms were gathered by the Hellenic Statistical Authority while the search regarding the financial data of the financial statements was carried out by ICAP GROUP SA.

The data and characteristics of the final sample of the bankrupt firms are as follows:

The number of firms in the sample amounted to 385 and concerns firms whose published financial data refer to the period $2003-2014$.

. All the firms in the sample have the legal form of the public limited company and belong to the trade and manufacturing sectors.

- Bankruptcy is the result of the formal bankruptcy process.

- The financial statements of the sample firms were prepared based on the principles of the Greek General Accounting Standards.

- In the case of non-availability of financial statements, for some years before bankruptcy, the latest available data were used.

. A random sample of 385 non-bankrupt firms, which were matched to the bankrupt ones, based on year, sector and sub-sector was selected. The random selection procedure is preferred to avoid bias problems.

- The sample of both bankrupt and healthy businesses includes profitable (whose bankruptcy was probably due to liquidity problems) and loss-making firms.

. The sample included firms whose net sales were less than $€ 40,000,000$.

\section{Methodology - Econometric Analysis}

For the purposes of the research, the planning of the analysis includes the following steps:

Application of factor analysis to select appropriate financial ratios (independent variables). 
- Separating sample firms into two sub periods. The period before the economic crisis (2003-2008) and in the period 2009 - 2014, during which the Greek economy was in crisis and recession.

- Developing discriminant analysis (MDA) and Logit probability (Logit) models for each period in order to find those firms that while bankrupt, appear healthy for their last operating period (Type I error).

- Selection of those firms that appear to be healthy while bankrupt, which are common set in the classification for both models, for the $1^{\text {st }}$ and $2^{\text {nd }}$ year before bankruptcy.

- Investigating and reviewing the actual financial information of the above firms during the last two years of their pre-bankruptcy period in order to determine whether they have been affected by potential earnings management and what possible practices have been followed.

\subsection{Selection of Financial Ratios (Independent Variables)}

The criteria with which the financial indicators were initially selected are:

- Their usefulness and explanatory power, which has been acknowledged in earlier studies for other countries as well (Chen KH, Shimerda TA., 1981).

- Their frequency and popularity, with which they appear in the relative literature (Altman E., 1968).

- Coverage of all operational features of the company such as Liquidity, Activity, Capital Efficiency, Capital Structure (Dambolena I, Khoury S., 1980).

Table1 presents the financial ratios that cover a wide range of information and underline the qualitative features of the samples.

Table 1. Variables description

\begin{tabular}{llll}
\hline Variable & Description & Variable & Description \\
\hline x1 & Sales to Total Assets & x8 & Net Profit Margin \\
x2 & EBIDTA to Total Assets & x9 & Return on Capital Employed \\
x3 & Net Working Capital to Total Assets & x10 & Return on Equity \\
x4 & Total Liabilities to Total Assets & x11 & Interest Coverage by EBITDA \\
x5 & Current Assets to Current Liabilities & x12 & Sales to Receivables \\
x6 & Gross Profit Margin & x13 & Total Reserves to Total Assets \\
x7 & Equity to Total Liabilities & x14 & Operating Cash Flows to Total Assets \\
\hline
\end{tabular}

The method of factor analysis (see, e.g. Kim JO, Mueller CW., 1978 and Kim JO, Mueller CW., 1978) was used for the identification and selection of the most appropriate financial ratios to be used in the application of bankruptcy prediction models. This statistical procedure is designed to reduce the number of parameters of the problem being analyzed. The reduction is achieved by minimizing the initial number of financial ratios (independent variables) to a level that allows for better management, provided that the final number of variables retains as much as possible the information that was given on the problem by the initial number of variables. 


\subsection{Factor Analysis}

The descriptive statistics on the bankrupt and healthy firms in the sample are listed in the table 2 below.

Table 2. Descriptive statistics of bankrupt firms in the sample

\begin{tabular}{llcccc}
\hline Variable description & Variable & Mean & Std. Dev. & Min & Max \\
\hline Sales to Total Assets & x1 & 1.17 & 1.15 & 0.02 & 8.81 \\
Ebitda to Total Assets & x2 & 0.04 & 0.10 & -0.47 & 0.36 \\
Net Working Capital to Total Assets & x3 & 0.08 & 0.27 & -1.07 & 0.77 \\
Total liabilities to Total Assets & x4 & 0.79 & 0.23 & 0.14 & 1.77 \\
Current Assets to Current Liabilities & x5 & 1.43 & 1.79 & 0.17 & 15.84 \\
Gross Profit Margin & x6 & 0.27 & 0.16 & 0.02 & 1.00 \\
Equity to Total liabilities & x7 & 0.44 & 0.84 & -0.43 & 6.21 \\
Net Profit Margin & x8 & -0.07 & 0.35 & -2.65 & 0.25 \\
Return on Capital Employed & x9 & -0.01 & 0.11 & -0.64 & 0.30 \\
Return on Equity & x10 & 0.11 & 1.00 & -4.96 & 5.75 \\
Ebitda to interest expenses & x11 & 3.58 & 40.62 & -206.79 & 411.05 \\
Sales to Receivables & x12 & 6.03 & 20.61 & 0.06 & 192.18 \\
Total Reserves to Total Assets & x13 & -0.05 & 0.31 & -2.01 & 0.34 \\
Operating Cash Flows to Total Assets & x14 & 0.04 & 0.15 & -0.45 & 0.58
\end{tabular}

The procedure is essentially based on the estimations of the common factors, as follows: a) estimating the correlations of the variables, b) determining the number of factors and estimating the model, c) Interpreting the factors in better way by rotating the model, d) affirmation of the adequacy of the model.

Table 3. Factor variance - factor weights

\begin{tabular}{|c|c|c|c|c|}
\hline Factors & Eigenvalues & Differences & Proportions & Cumulative \\
\hline $\mathrm{F} 1$ & 3.75 & 1.21 & 0.27 & 0.27 \\
\hline $\mathrm{F} 2$ & 2.55 & 1.12 & 0.18 & 0.45 \\
\hline F3 & 1.43 & 0.37 & 0.10 & 0.55 \\
\hline $\mathrm{F} 4$ & 1.06 & 0.05 & 0.08 & 0.63 \\
\hline F5 & 1.01 & 0.09 & 0.07 & 0.70 \\
\hline F6 & 0.92 & 0.07 & 0.07 & 0.77 \\
\hline F7 & 0.85 & 0.22 & 0.06 & 0.83 \\
\hline F8 & 0.64 & 0.08 & 0.05 & 0.87 \\
\hline F9 & 0.55 & 0.05 & 0.04 & 0.91 \\
\hline F10 & 0.51 & 0.17 & 0.04 & 0.95 \\
\hline F11 & 0.34 & 0.10 & 0.02 & 0.97 \\
\hline F12 & 0.25 & 0.15 & 0.02 & 0.99 \\
\hline F13 & 0.10 & 0.05 & 0.01 & 1.00 \\
\hline F14 & 0.05 & & 0.00 & 1.00 \\
\hline
\end{tabular}

Tables 3 and 4 below show the results of the factor analysis of the model, with the 14 variables. The "cumulative" column in table 3 shows the percentage of the model variance that is explained each time, taking into account the use of a different number of factors. We conclude that at least $70 \%$ of the total variance is explained by using five factors. In addition, the "Uniqueness" column in table 4 displays the variance percentage of each variable which is not explained by the common factors that proposed by factor analysis. A rule of thumb is that larger values than 0.6 indicate that the 
variance of the variable is not adequately explained by the common factors (e.g. the case of variable $\mathrm{x} 14$ ). The variables with the higher loading at each factor are appropriate for the analysis.

Table 4. Rotated factor loadings (pattern matrix) and unique variances

\begin{tabular}{lllllll}
\hline Variable & F1 & F2 & F3 & F4 & F5 & Uniqueness \\
\hline x1 & 0.18 & -0.06 & 0.80 & 0.07 & 0.02 & 0.31 \\
x2 & 0.90 & -0.05 & -0.01 & 0.08 & 0.11 & 0.16 \\
x3 & 0.26 & 0.72 & 0.01 & -0.18 & -0.04 & 0.32 \\
x4 & 0.92 & 0.03 & 0.00 & 0.04 & 0.05 & 0.13 \\
x5 & -0.13 & 0.94 & 0.02 & 0.08 & 0.05 & 0.15 \\
x6 & 0.15 & 0.04 & -0.68 & 0.38 & -0.15 & 0.34 \\
x7 & -0.11 & 0.93 & -0.02 & 0.09 & 0.03 & 0.14 \\
x8 & 0.79 & 0.03 & 0.06 & 0.11 & 0.00 & 0.34 \\
x9 & -0.30 & -0.74 & 0.07 & 0.20 & 0.07 & 0.23 \\
x10 & 0.11 & 0.00 & 0.02 & 0.80 & 0.05 & 0.33 \\
x11 & 0.05 & 0.03 & 0.01 & 0.02 & 0.95 & 0.09 \\
x12 & -0.07 & 0.10 & 0.62 & 0.30 & -0.25 & 0.47 \\
x13 & 0.76 & 0.01 & 0.02 & -0.20 & -0.16 & 0.39 \\
x14 & 0.37 & -0.02 & -0.03 & 0.24 & 0.00 & 0.80
\end{tabular}

Finally, taking into account the results of the factor analysis, the variables used in the two models are as follows:

Table 5. Variables used in the models

\begin{tabular}{ll}
\hline Variable description & Variables \\
\hline Sales to Total Assets & $\mathrm{x} 1$ \\
Ebitda to Total Assets & $\mathrm{x} 2$ \\
Debt to Total Assets & $\mathrm{x} 4$ \\
Current Assets to Current Liabilities & $\mathrm{x} 5$ \\
Interest Coverage by EBITDA & $\mathrm{x} 11$ \\
\hline
\end{tabular}

\subsection{Econometric Analysis}

The techniques chosen to investigate the prediction of failure and bankruptcy of the firms are the methods of multiple discriminant analysis (MDA) and logarithmic probability model (Logit).

\subsubsection{The Method of Linear Discriminant Analysis}

Discriminant analysis (for a presentation of the method, see, e.g. McLachlan GJ., 1992) is used in order to describe the differences between two or more groups, with a view to exploiting these differences so as to classify to a known group any observation that is not known to which group it belongs. Assuming that in each group $i$, the cumulative distribution function of variables $\mathbf{x}$ is normal with mean $\mu_{l}$ and co-variance $\Sigma$, identical for each group, the following formula is used. It is noted that the equal variance condition should be met; otherwise a non-linear method should be chosen (e.g. quadratic discriminant analysis) :

$$
f\left(\mathbf{x} \mid \mu_{i}, \Sigma\right)=\frac{1}{(2 \pi)^{p / 2}|\Sigma|^{1 / 2}} e^{-\frac{1}{2}\left(\mathbf{x}-\mu_{i}\right) \Sigma\left(\mathbf{x}-\mu_{i}\right)}
$$

The above formula classifies each observation in the group for which the probability $p_{i} \mathrm{f}\left(\mathbf{x} \mid \mu_{l}\right)$ is greater.

The classification (discriminant) function is a linear combination of independent variables (financial ratios, $\mathbf{x}$ ), which isolates those characteristics from the observations under consideration, which make the discrimination of the groups distinct, giving a score $\mathrm{Z}$ to each enterprise:

$$
Z=b_{1} x 1_{i}+b_{2} x 2_{i}+\cdots+b_{k} x k_{i}
$$

where

$b_{v}$ : discriminant coefficients 
$\mathrm{X}_{\mathrm{v}}$ : independent variables,

$\mathrm{v}=1,2 . ., \mathrm{k}$, the number of variables,

and $\mathrm{Z}$ the discriminant score.

The discrimination will be better as the variance between the groups is high and the variance within the group is low.

4.3.2 The Logarithmic Probability Model (Logit)

The Logit model is a nonlinear regression model specifically designed to estimate dependent binary variables. It gives the probability that the dependent variable will get the value 1, given the values of the independent variables, by adopting techniques leading the estimated values to fluctuate in the range $(0,1)$. Logit models use the cumulative standard logistic distribution function to predict the probability that the dependent variable gets the value 1 :

$$
\operatorname{Pr}\left(y_{i}=1 \mid x_{i}\right)=\frac{e^{x_{i} b}}{1+e^{x_{i} b}}
$$

Therefore, according to the above, the model to be used is in the form:

$$
\boldsymbol{P r}(y=1 \mid \mathbf{x})=\boldsymbol{F}\left(c+b_{1} x 1+b_{2} x 2+\cdots+b_{k} x k\right)
$$

\section{Results}

Applying the models of discriminant analysis and Logit, the results for the two periods and for the $1^{\text {st }}$ and $2^{\text {nd }}$ year before the actual bankruptcy of the 385 firms are shown in Table 6 below.

\begin{tabular}{|c|c|c|c|c|}
\hline & \multicolumn{2}{|c|}{ PRE-CRISIS PERIOD } & \multicolumn{2}{|c|}{ CRISIS PERIOD } \\
\hline & $\underline{2003-2008}$ & & $\underline{2009-201}$ & \\
\hline & $\underline{1}^{\text {st }}$ Year & $\underline{2^{\text {nd }}}$ Year & $1^{\text {st }}$ Year & $\underline{2^{\text {nd }}}$ Year \\
\hline & 172 firms & $\underline{172 \text { firms }}$ & 213 firms & $\underline{213 \text { firms }}$ \\
\hline MDA & $61,90 \%$ & $66,67 \%$ & $77,38 \%$ & $72,61 \%$ \\
\hline LOGIT & $61,90 \%$ & $75,00 \%$ & $81,30 \%$ & $76,47 \%$ \\
\hline
\end{tabular}

Table 6. Comparative table of prediction of bankrupt firms in the sample

In the period before the financial crisis, 2003-2008, the predictive capacity of the MDA and Logit models declined in the last year before bankruptcy, which is not the case during the economic crisis 2009-2014.This leads us to the conclusion that in the period before the financial crisis, earnings management practices were applied by the firms in order to improve their financial statements. The analysis of the total of 385 bankrupt firms in the sample showed that 84 firms in the last accounting period before the bankruptcy were ranked as healthy for both MDA and Logit models, while in fact during that period they were bankrupt (Type I error): 43 during the period 2003-2008 and 41 during 2009-2014.The upward trend in inventories and sales (Tables 7 and 8), as the bankruptcy firms approach the collapse, in the last year before that, reinforces the conclusion that creative accounting was exercised by the managers, with the aim of increasing profitability or reducing losses by misrepresenting the financial statements, which is achieved by intervening both in the end-of-year inventory and in sales.

Table 7. Inventories, sales, and profits evolution of means, period $2003-2008$

\begin{tabular}{lllll}
\hline $\begin{array}{l}\text { YEAR BEFORE } \\
\text { BANKRUPTCY }\end{array}$ & INVENTORIES & SALES & PROFITS & $\begin{array}{l}\text { NUMBER } \\
\text { OF FIRMS }\end{array}$ \\
\hline-1 & 2.251 .628 & 10.230 .365 & 227.594 & 20 \\
-2 & 1.985 .159 & 8.992 .093 & 164.565 & 20 \\
\hline
\end{tabular}

Table 8. Inventories, sales, and losses evolution of means, period $2003-2008$

\begin{tabular}{lllll}
\hline $\begin{array}{l}\text { YEAR BEFORE } \\
\text { BANKRUPTCY }\end{array}$ & INVENTORIES & SALES & LOSSES & $\begin{array}{l}\text { NUMBER } \\
\text { OF FIRMS }\end{array}$ \\
\hline-1 & 2.341 .512 & 8.955 .637 & -478.299 & 23 \\
-2 & 1.907 .173 & 7.767 .205 & -628.865 & 23 \\
\hline
\end{tabular}


In contrast, during the period of the financial crisis and the recession of the Greek economy, from 2009 to 2014, there is a normal evolution of inventories, sales, profits and losses in relation to the time of bankruptcy, showing downward trends in the evolution of stocks, sales, and profits and upward trends in losses (Tables 9 and 10).

Table 9. Inventories, sales, and profits evolution of means, period $2003-2008$

\begin{tabular}{lllll}
\hline $\begin{array}{l}\text { YEAR BEFORE } \\
\text { BANKRUPTCY }\end{array}$ & INVENTORIES & SALES & PROFITS & $\begin{array}{l}\text { NUMBER } \\
\text { OF FIRMS }\end{array}$ \\
\hline-1 & 1.592 .759 & 11.360 .550 & 155.253 & 17 \\
-2 & 1.617 .729 & 12.053 .088 & 184.010 & 17 \\
\hline
\end{tabular}

Table 10. Inventories, sales, and losses evolution of means, period $2003-2008$

\begin{tabular}{lllll}
\hline $\begin{array}{l}\text { YEAR } \\
\text { BANKRUPTCY }\end{array}$ & INVENTORIES & SALES & LOSSES & $\begin{array}{l}\text { NUMBER } \\
\text { OF FIRMS }\end{array}$ \\
\hline-1 & 1.062 .576 & 3.164 .163 & -864.729 & 24 \\
-2 & 2.099 .816 & 6.613 .186 & -577.188 & 24 \\
\hline
\end{tabular}

\section{Conclusions}

According to the results of the prediction for the bankrupt firms, in the trade and manufacturing sector there is a possible manipulation of the financial data, with the aim of falsifying-embellishing the financial statements, which is documented as follows:

For the period 2003-2008, the predictive ability of the MDA and Logit models is declining in the last year before bankruptcy compared to previous years. Normally, the rate of predictive capacity is rising as an enterprise approaches bankruptcy, as there is a steady deterioration over time. This fact of the worst overall behavior of the two models, a year before bankruptcy, compared to previous years, leads us to the conclusion that financial data of a number of firms are being altered by using creative accounting methods.

Examining the actual financial data of the firms (common to both models) that appear to be solvent while they were bankrupt during the next accounting period (type I error), it is revealed that there is a significant improvement in key financial figures such as sales, or overestimation of assets and earnings in the last year of their operation before bankruptcy compared to previous years.

As can be seen from the analysis of real accounting data, the methods of altering them were based on:

The increase in sales which is achieved either by creating fictitious sales or by manipulating real activities giving excessive discounts.

The deterioration of the end-of-year inventory, which affects, on the one hand, the results of the end of the year (showing profits or decreasing the losses) and, on the other hand, on the balance sheet and in particular on current assets.

In contrast, the percentage of the predictive capacity of the models (MDA) and (Logit) in the period 2009 - 2014, when the Greek economy was in crisis and recession, appear as to have been increasing in the last year before bankruptcy, compared to previous years, which is considered normal and leads us to the conclusion that managers do not exercise creative accounting in this particular period. This is explained by the fact that in times of recession the economic difficulties of already burdened firms are even more serious, and the managers' effort to alter financial data and results are limited. In addition the intensity of utilizing creative accounting is reduced because the economic crisis creates new conditions in the market resulting in a change of suppliers' and banks' credit policy as well as of household consumption behavior, which affects firms' costs and revenues.

\section{References}

Altman E. (1968). Financial Ratios, Discriminant Analysis and the Prediction of Corporate Bankruptcy. The Journal of Finance, 23(4), 589-609. https://doi.org/10.1111/j.1540-6261.1968.tb00843.x

Argenti J. (1976). Corporate planning and corporate collapse. Long Range Planning, 9(6), 12-17. https://doi.org/10.1016/0024-6301(76)90006-6

Barua A, Lin S, Sbaraglia A. (2010). Earnings management using discontinued operations. The Accounting Review, 85(5), 1485-1509. https://doi.org/10.2308/accr.2010.85.5.1485 
Beasley MS, Carcello JV, Hermanson DR, Nead TL. (2010). Fraudelent Financial Reporting 1998 - 2007. An Analysis of U.S. Public Companies. COSO. 2010; http://www.coso.org/documents/cosofraudstudy2010.pdf

Bhattacharya U, Daouk H, Welker M. (2003). The world price of earnings opacity. The Accounting Review, 78(3), 641-678. https://doi.org/10.2308/accr.2003.78.3.641

Bryan D, Janes T, Tiras SL. (2014). The role that fraud has on bankruptcy and bankruptcy emergence. Journal of Forensic and Investigative Accounting, 6(2), 126-156.

Campa D, Camacho-Minano M. (2014). Earnings management among bankrupt non-listed firms: evidence from Spain. Spanish Journal of Finance and Accounting, 43(1), 3-20. https://doi.org/10.1080/02102412.2014.890820

Charitou A, Lambertides N, Trigeorgis L. (2007b). Earnings behaviour of financially distressed firms: The role of institutional ownership. Abacus, 43(3), 271-296. https://doi.org/10.1111/j.1467-6281.2007.00230.x

Charitou A, Lambertides N, Trigeorgis L. (2007a). Managerial discretion in distressed firms. The British Accounting Review, 39(4), 323-346. https://doi.org/10.1016/j.bar.2007.08.003

Chen KH, Shimerda TA. (1981). An Empirical Analysis of Useful Financial Ratios. Financial Management, 10(1), 51-60. https://doi.org/10.2307/3665113

Dambolena I, Khoury S. (1980). Ratio stability and corporate failure. The Journal of Finance, 35(4), 1017-1026. https://doi.org/10.1111/j.1540-6261.1980.tb03517.x

Dechow P, Sloan R, Sweeney A. (1995). Detecting Earnings Management. The Accounting Review, 70(2), 193-225.

Degeorge F, Patel J, Zeckhauser, R. (1999). Earnings Management to Exceed Thresholds. Journal of Business, 72(1), 1-33. https://doi.org/10.1086/209601

Dutzi A, Rausch B. (2016). Earnings Management before Bankruptcy: A Review of the Literature. Journal of Accounting and Auditing: Research \& Practice. https://doi.org/10.5171/2016.245891

Habib A, Bhuiyan MBU, Islam A. (2013). Financial distress, earnings management and market pricing of accruals during the global financial crisis. Managerial Finance, 39(2), 155-180. https://doi.org/10.1108/03074351311294007

Healy PM, Palepu KG. (2003). The Fall of Enron. Journal of Economic Perspectives, 17(2), 3-26. https://doi.org/10.1257/089533003765888403

Howe J, Houston R. (2016). Earnings Management, Earnings Surprises and Distressed Firms. Accounting and Finance Research, 5(1), 64-87. https://doi.org/10.5430/afr.v5n1p64

Humeedat MM. (2018). Earnings Management to Avoid Financial Distress and Improve Profitability: Evidence from Jordan. International Business Research, 11(2), 222 https://doi.org/10.5539/ibr.v11n2p222

Jones J. (1991). Earnings management during import relief investigations. Journal of Accounting Research, 29(2), 193-228. https://doi.org/10.2307/2491047

Kalunki JP, Martikainen T. (1999). Financial failure and managers accounting responses: Finnish evidence. Journal of Multinational Financial Management, 9, 15-26. https://doi.org/10.1016/S1042-444X(98)00046-2

Kim JO, Mueller CW. (1978). Factor analysis: Statistical methods and practical issues. (Sage University Paper Series on Quantitative Applications in the Social Sciences, series no. 1978b; 07-014). Newbury Park, CA: Sage.

Kim JO, Mueller CW. (1978). Introduction to factor analysis: What it is and how to do it", (Sage University Paper Series on Quantitative Applications in the Social Sciences, series no.1978a; 07-013). Newbury Park, CA: Sage.

Lara JMG, Osma BG, Neophytou E. (2009). Earnings quality in ex-post failed firms. Accounting and Business Research, 39(2), 119-138. https://doi.org/10.1080/00014788.2009.9663353

Leuz C, Nanda D, Wysocki P. (2003). Earnings Management and Investor Protection: an International Comparison. Journal of Financial Economics, 69(3), 505-527. https://doi.org/10.1016/S0304-405X(03)00121-1

McLachlan GJ. (1992). Discriminant Analysis and Statistical Pattern Recognition. John Wiley \& Sons Inc., New York. https://doi.org/10.1002/0471725293

Miko NU, Kamardin H. (2014). Detecting Earnings Management: Comparative Analysis of Models in Nigeria. Journal of Accounting Frontier, 16(2), 68-76. 
Nagar Neerav, Sen Kaustav. (2016). Earnings Management Strategies during Financial Distress. Working paper, Indian Institute of Management. (IIM-AHMEDABAD), 1-42

Ranjbara S, Gholamreza FA. (2018). The effect of financial distress on earnings management and unpredicted net earnings in companies listed on Tehran Stock Exchange. Management Science Letters, 8, 933-938. https://doi.org/10.5267/j.msl.2018.6.015

Rezaee Z, Rilay R. (2009). Financial Statement Fraud. Prevention and Detection. 2nd Edition, John Wiley and Sons, NY, ISBN: 978-0-470-45570-8

Rosner RL. (2003). Earnings manipulation in failing firms. Contemporary Accounting Research, 20(2), 361-408.https://doi.org/10.1506/8EVN-9KRB-3AE4-EE81

Roychowdhury S. (2006). Earnings management through real activities manipulation. Journal of Accounting and Economics, 42(3), 335-370. https://doi.org/10.1016/j.jacceco.2006.01.002

Smith M, Kestel J, Robinson P. (2001). Economic recession, corporate distress and income increasing accounting policy choice. Accounting Forum, 25(4), 335-352. https://doi.org/10.1111/1467-6303.00070

Sweeney A. (1994). Debt covenant violations and managers' responses. Journal of Accounting and Economics, 17(3), 281-308. https://doi.org/10.1016/0165-4101(94)90030-2

\section{Appendix}

\section{Period $2003-2008$, before the financial crisis}

1.1. One year before bankruptcy (sample size: 172 firms)

Table 11. Estimation of model coefficients

\begin{tabular}{llll}
\hline Variable & $\underline{\text { Models }}$ & & \\
& $\underline{\text { Discriminant }}$ & $\underline{\text { Logit }}$ & \\
& $\underline{\text { Unstandardized coef. }}$ & $\underline{\text { Coefficients }}$ & $\underline{\text { p-values }}$ \\
\hline X1 & -0.93 & -1.56 & 0.06 \\
X2 & -1.25 & 3.37 & 0.49 \\
X4 & 0.63 & 7.55 & 0.04 \\
X5 & -0.10 & -0.12 & 0.90 \\
X11 & 0.00 & -0.02 & 0.20 \\
Cons & -0.63 & -4.45 & 0.18 \\
\hline
\end{tabular}

Table 12. Predictive capacity of the models

\begin{tabular}{lll}
\hline Predictive capacity & $\begin{array}{l}\text { Models } \\
\text { Discriminant }\end{array}$ & Logit \\
\hline Prediction of bankrupt & $61.90 \%$ & $61.90 \%$ \\
Prediction of healthy & $66.67 \%$ & $76.19 \%$ \\
Total prediction & $64.29 \%$ & $69.05 \%$ \\
Type I error & $38.10 \%$ & $38.10 \%$ \\
Type II error & $33.33 \%$ & $23.81 \%$ \\
Total error & $35.71 \%$ & $30.95 \%$ \\
\hline
\end{tabular}


1.2. Two years before bankruptcy (sample size: 172 firms)

Table 13. Estimation of model coefficients

\begin{tabular}{llll}
\hline Variable & Models & & \\
& Discriminant & Logit & \\
& Unstandardized coef. & Coefficients & p-values \\
\hline X1 & -0.02 & -0.05 & 0.91 \\
X2 & -7.57 & -13.76 & 0.01 \\
X4 & 2.81 & 4.20 & 0.08 \\
X5 & -0.13 & -0.01 & 0.99 \\
X11 & 0.00 & 0.00 & 0.28 \\
ConS & -1.68 & -2.56 & 0.26 \\
\hline
\end{tabular}

Table 14. Predictive capacity of the models

\begin{tabular}{lll}
\hline Predictive capacity & $\begin{array}{l}\text { Models } \\
\text { Discriminant }\end{array}$ & Logit \\
\hline Prediction of bankrupt & $66.67 \%$ & $75.00 \%$ \\
Prediction of healthy & $75.00 \%$ & $75.00 \%$ \\
Total prediction & $70.83 \%$ & $75.00 \%$ \\
Type I error & $33.33 \%$ & $25.00 \%$ \\
Type II error & $30.14 \%$ & $25.00 \%$ \\
Total error & $29.17 \%$ & $25.00 \%$ \\
\hline
\end{tabular}

\section{Period $2009-2014$, during the financial crisis}

2.1 One year before bankruptcy (sample size: 213 firms)

Table 15. Estimation of model coefficients

\begin{tabular}{llll}
\hline Variable & Models & Logit & \\
& $\begin{array}{l}\text { Discriminant } \\
\text { Unstandardized coef. }\end{array}$ & Coefficients & p-values \\
\hline $\mathrm{X} 1$ & -0.23 & -0.86 & 0.21 \\
$\mathrm{X} 2$ & -3.36 & -38.43 & 0.03 \\
$\mathrm{X} 4$ & 1.51 & 8.59 & 0.02 \\
$\mathrm{X} 5$ & -0.02 & -0.33 & 0.14 \\
$\mathrm{X} 11$ & 0.00 & -0.11 & 0.43 \\
$\mathrm{ConS}$ & -0.95 & -3.60 & 0.11 \\
\hline
\end{tabular}


Table 16. Predictive capacity of the models

\begin{tabular}{lll}
\hline Predictive capacity & Models & Logit \\
\hline Prediction of bankrupt & Discriminant & $81,30 \%$ \\
Prediction of healthy & $77,38 \%$ & $87.30 \%$ \\
Total prediction & $87,30 \%$ & $84.30 \%$ \\
Type I error & $82,34 \%$ & $18,70 \%$ \\
Type II error & $22.62 \%$ & $12.70 \%$ \\
Total error & $12.70 \%$ & $15,70 \%$ \\
\hline
\end{tabular}

2.2. Two years before bankruptcy (sample size: 213 firms)

Table 17. Assessment of model coefficients

\begin{tabular}{|c|c|c|c|}
\hline \multirow{3}{*}{ Variable } & \multicolumn{3}{|l|}{ Models } \\
\hline & Discriminant & Logit & \\
\hline & Unstandardized coef. & $\Sigma v v \tau \varepsilon \lambda \varepsilon \sigma \tau \dot{\varepsilon} \varsigma$ & p-values \\
\hline $\mathrm{X} 1$ & 0.06 & 0.07 & 0.91 \\
\hline $\mathrm{X} 2$ & -4.71 & 6.75 & 0.60 \\
\hline $\mathrm{X} 4$ & 3.08 & 8.91 & 0.01 \\
\hline X5 & -0.06 & -0.13 & 0.46 \\
\hline X11 & 0.00 & -0.42 & 0.15 \\
\hline ConS & -2.29 & -6.48 & 0.02 \\
\hline
\end{tabular}

Table 18. Predictive capacity of the models

\begin{tabular}{lll}
\hline Predictive capacity & $\begin{array}{l}\text { Models } \\
\text { Discriminant }\end{array}$ & Logit \\
\hline Prediction of bankrupt & $72.61 \%$ & $76,47 \%$ \\
Prediction of healthy & $82.61 \%$ & $82.61 \%$ \\
Total prediction & $77,61 \%$ & $79,54 \%$ \\
Type I error & $27.39 \%$ & $23,53 \%$ \\
Type II error & $17.39 \%$ & $17.39 \%$ \\
Total error & $22,39 \%$ & $20.46 \%$ \\
\hline
\end{tabular}

